\title{
Polyarticular tophaceous gouty arthritis: A case report
}

\author{
Sheikh Javeed Ahmad, Sumyra Khurshid
}

\begin{abstract}
Introduction: Gout is a disorder of purine metabolism, affecting men 40-50 years of age resulting in recurrent bouts of arthritis and subcutaneous tophi in patients with long standing disease. We report a case of a 45-year-old male with symmetric, deforming polyarticular arthritis, affecting all the joints of hands, wrists and feet with diffuse subcutaneous nodules over his body. The radiographic findings of the patient were atypical. Following clinical evaluation and additional investigations, the patient received a diagnosis of chronic tophaceous gouty arthritis mimicking rheumatoid arthritis.
\end{abstract}

Keywords: Gout, Arthritis, Tophi, Hand, Foot

$* * * * * * * * *$

Ahmad SJ, Khurshid S. Polyarticular tophaceous gouty arthritis: A case report. International Journal of Case Reports and Images 2013;4(10):554-558.

$* * * * * * * * *$

doi:10.5348/ijcri-2013-10-378-CR-7

Sheikh Javeed Ahmad ${ }^{1}$, Sumyra Khurshid ${ }^{2}$

Affiliations: ${ }^{1}$ Departments of Physical Medicine and Rehabilitation, Sher I Kashmir Institute of Medical Sciences, Srinagar, India; '2Departments of Pathology, Sher I Kashmir Institute of Medical Sciences, Srinagar, India.

Corresponding Author: Sheikh Javeed Ahmad, Departments of Physical Medicine and Rehabilitation, Sher I Kashmir Institute of Medical Sciences, Srinagar 190011, India; Email: javeed.sk@rediffmail.com

Received: 26 March 2013

Accepted: 17 June 2013

Published: 01 October 2013

\section{INTRODUCTION}

Gout is a metabolic disorder of purine degradation pathway usually affecting middle aged and elderly men and postmenopausal females. Usually, it results in acute, monoarticular arthritis, intercritical period and chronic tophaceous gout associated with hyperuricemia and characterized by the presence of monosodium urate (MSU) crystals in connective tissues and kidneys [1, 2]. However, some patients develop chronic polyarthritis mimicking rheumatoid arthritis [3-6]. Both disease entities have been reported to occur in adult population to the extent of approximately $1 \%[2,7,8]$ with symmetric polyarthritis. Symmetrical presentation or positive rheumatoid factor (RF) can be seen in both the diseases. A few cases of polyarticular tophaceous gout have been reported in literature $[9,10]$. We report a rare case of a 45-year-old male with polyarticular tophaceous gout with atypical involvement of hand and feet with disabling effects of untreated hyperuricemia.

\section{CASE REPORT}

A 45-year-old male (from Kashmir) was presented to our department of physical medicine and rehabilitation at Sher-i-Kashmir Institute of Medical sciences (Srinagar) a multispecialty hospital with long standing history of pain, swelling and deformity of small and large joints of both hands and feet for approximately 12 years. The patient reported with the history of polyarthralgia which had improved over a week's time. This was followed by frequent intermittent episodes of arthritis of small and large joints of hands, knees, wrists, ankles and feet without morning stiffness. The disease had been treated symptomatically with non-specific non-steroid anti-inflammatory drugs (NSAIDs) leading to the improvement over a period of time. Thereafter, patient developed recurrent episodes of polyarthritis with painless nodules on hand and feet. He was put on allopurinol for 6 months and dietary restriction of protein on account of hyperuricemia with serum uric acid levels of $12.43 \mathrm{mg} / \mathrm{dL}$. Patient intentionally interrupted the treatment following his betterment of health. 
When the patient visited the outpatient department of our clinic on first physical examination, he was conscious, afebrile, and normotensive. Cardiovascular and respiratory system parameters were normal. Physical examination of Locomotor system revealed muscle atrophy of all four limbs and interossei muscles of both hands; multiple deformities of wrists, metacarpophalangeal joints (MCP), proximal interphalangeal joints (PIP) of hands (Figure 1) and metatarsophalangeal joints of feet (Figure 2). Skin examination showed subcutaneous nodule of different sizes, measuring 1-2 $\mathrm{cm}$ along metacarpophalangeal joints (MCP) and proximal interphalangeal joints (PIP) of hands (Figure 1) metatarsophalangeal joints feet (Figure 2). These nodules were not showing any signs of inflammation and were fixed to deeper tissues.

Laboratory workup revealed hemoglobin $12.1 \mathrm{~g} / \mathrm{dL}$, Leukocyte counts of $4,300 / \mu \mathrm{L}$, platelet counts of $150 \times 10^{3} / \mu \mathrm{L}$, ESR of $14 / \mathrm{mm}$ Ist hr, uric acid of $14 \mathrm{mg} / \mathrm{dL}$, creatinine of $1.35 \mathrm{mg} / \mathrm{dL}$, rheumatoid factor (RF) negative, blood glucose fasting of $110 \mathrm{mg} / \mathrm{dL}$. Urinary uric acid levels were $1.19 \mathrm{~g} / 24 \mathrm{hr}$ and creatinine clearance of $40 \mathrm{~mL} /$ $\mathrm{min} / 1.73 \mathrm{~m}^{2}$, C-reactive protein $15 \mathrm{mg} / \mathrm{L}$. X-ray of hands showed narrowing of joint space, subarticular cysts at proximal interphalangeal joint of middle finger of right hand with asymmetric soft tissue swelling (Figure 3 ). X-ray of feet showed the evidence of narrowing of joint spaces bilaterally with subarticular cysts and overhanging edges. There is complete osteolysis of little toe of right foot (Figure 4). Histopathological examination of nodule removed from left MCP joint revealed presence of uric acid crystals (tophus) with no atypical cells (Figure 5).

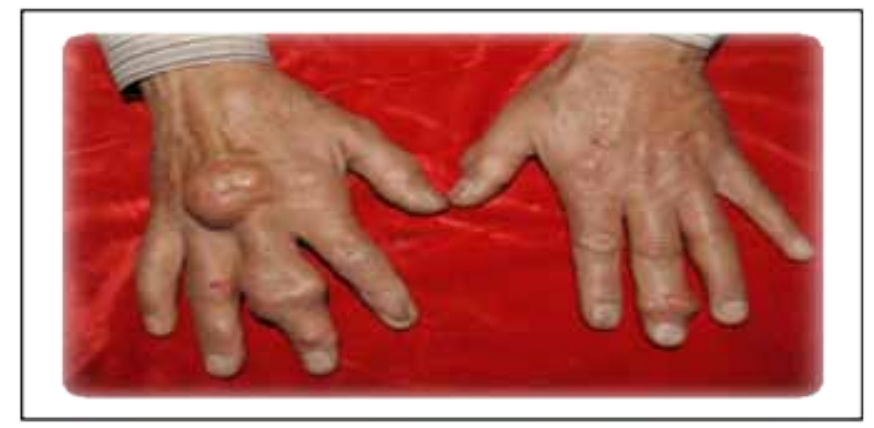

Figure 1: Tophaceous nodule on metacarple and interphalangeal joint of middle figure of right hand.

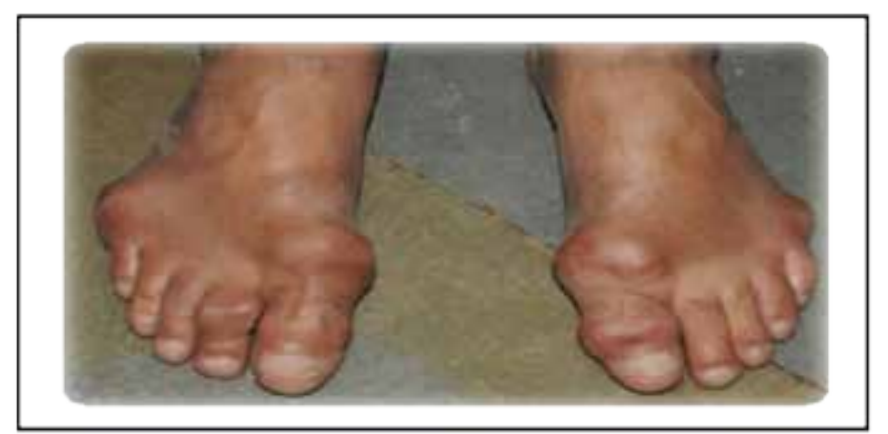

Figure 2: Tophaceousnodule index toe and little toe.
A diagnosis of polyarticular tophaceous gout was made and patient was treated with colchicine $0.5 \mathrm{mg} /$ day and febuxostat $40 \mathrm{mg} /$ day, which was increased to $1 \mathrm{mg} /$ day and $80 \mathrm{mg} /$ day respectively till acute stage. Currently, patient is showing good response with febuxostat $80 \mathrm{mg} /$ day alone.

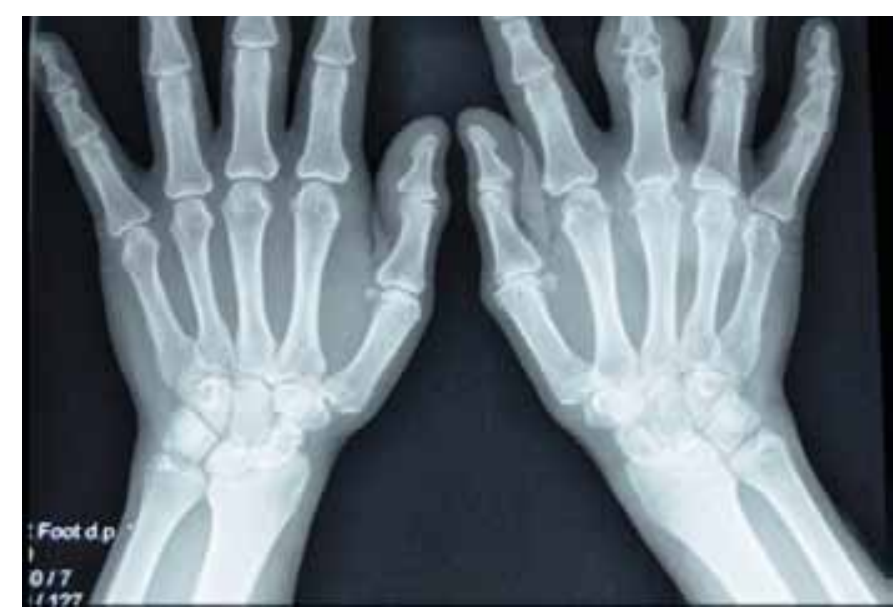

Figure 3: Bilateral soft tissue swelling, narrowing of space and subarticular cysts.

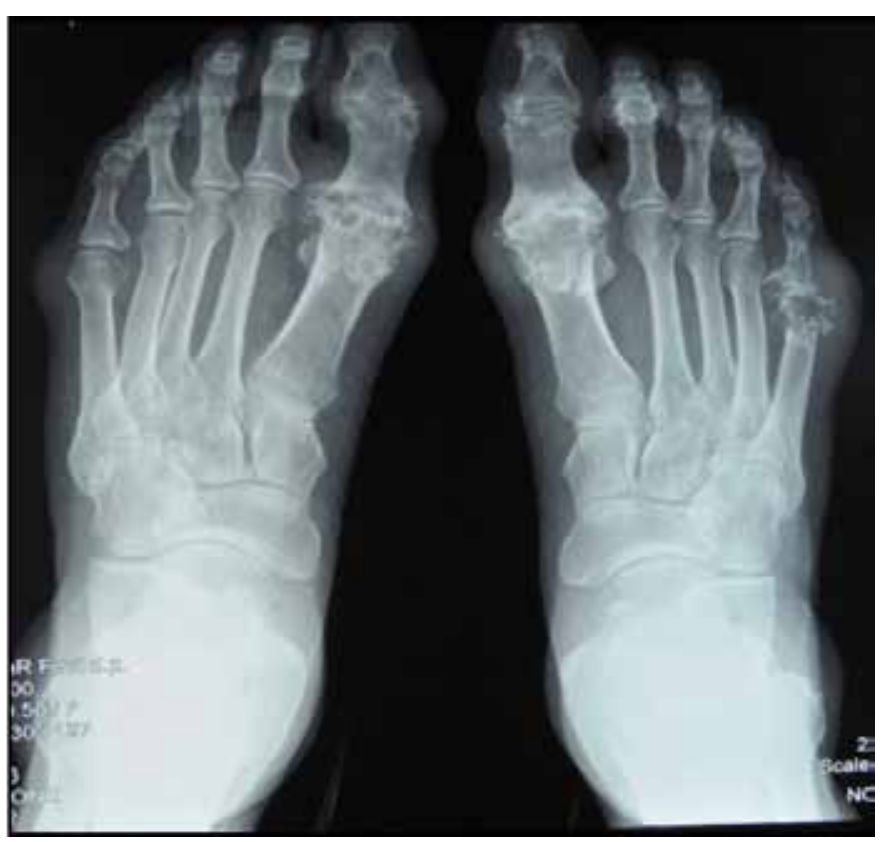

Figure 4: Subarticularsclerosis,cysts bilaterally and osteolysis of little toe of right foot.

\section{DISCUSSION}

Gout is an inflammatory arthropathy affecting $2.13 \%$ of population in United States of America in 2009 [11] with high preponderance for old age, male gender, postmenopausal females and black race [12]. Gout is a metabolic disorder which is characterized by elevation 


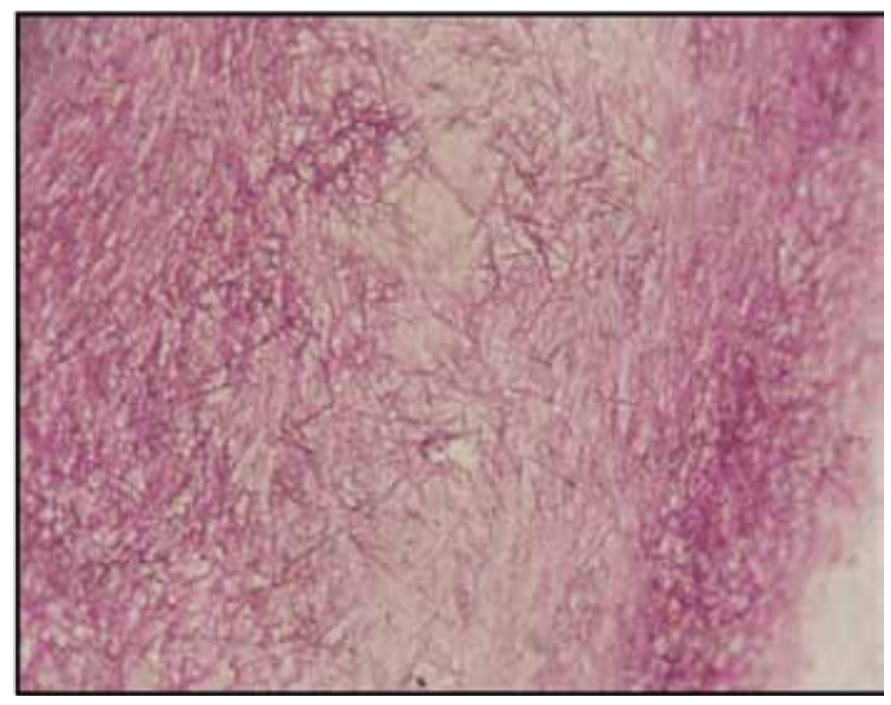

Figure 5: Monosodium urate crystals of tophi on microscopy.

of uric acid levels above $6.8 \mathrm{mg} / \mathrm{dL}$ resulting from impaired renal uric acid excretion. High uric acid level can be attributed to uric acid elevating drugs, genetic predisposition and dietary factors [13]. Gout is a metabolic disorder in which needle shaped crystal of monosodium urate from super saturated fluids are deposited in tissues resulting in gouty arthritis, tophi formation, uric acid nephrolithiasis and renal impairment [14, 15]. The tophi formation usually occurs over a mean period of 10 years [16]. Tophi are present commonly as subcutaneous, sharply circumscribed nodular collection of monosodium urate crystals [17] at periarticular site in and around bursae and in soft tissue overlying tendon and cartilage [18-20]. The most common locations are skin overlying joints and helix of the ears. Rarely, these are found in eyes, nose, larynx, breast and heart valves, penis, spinal cord, tongue, epiglottis [21-31]. Adel and Janitzia have reported location of intradermal tophi on legs, forearm, buttock, abdominal wall, palm and sole [32, 33].

The optimal serum urate level necessary for elimination of tissue deposits of monosodium urate in patients of chronic gout is controversial. Some studies reveal the decrease in serum urate levels achieved by urate lowering drugs and the fast reduction in tophaceous deposition [34]. Surgical treatment is seldom required for gout and is usually reserved for cases of recurrent attacks with deformities, severe pain and joint destruction [35]. The main indication of surgical intervention in gout is sepsis or infection of ulcerated tophi followed by mechanical problems, confirmation of diagnosis and pain control [36]. The radiologic changes in gouty arthritis are asymmetrical, erosive arthritis with preserved articular surface except in late cases. Bone erosions are usually caused by tophi deposits [10].

Almost 30\% of patients of rheumatoid arthritis have subcutaneous nodes and all these patients are usually seropositive. Thus polyarthritis with subcutaneous nodules with negative rheumatoid factor should be investigated for tophaceous gout [37]. Early diagnosis and initiation of early treatment of gouty arthritis will halt the progression of disease to tophaceous state. The current medical management of gouty arthritis has changed a lot. At present management of gout includes non-steroid antiinflammatory drugs (NSAIDs), colchicines and steroids. The intraarticular steroid has been mainstay to alleviate acute gouty arthritis. It is pertinent to mention interleukin 1 beta inhibitors are the future for amelioration of gouty syndrome. Rilonacept, an interleukin 1 antagonist has proven to be of great advantage in chronic gout and has been helpful in refractory gout but randomized control trails need to be done for its effectiveness.

\section{CONCLUSION}

Polyarticular tophaceous gouty arthritis is uncommon considering pharmacological treatment of hyperuricemia and such cases may be considered as differential diagnosis for rheumatoid arthritis so that early treatment will stop the disability effects in such patients.

$* * * * * * * * *$

\section{Author Contributions}

Sheikh Javeed Ahmad - Substantial contributions to conception and design, Acquisition of data, Analysis and interpretation of data, Drafting the article, Revising it critically for important intellectual content, Final approval of the version to be published

Sumyra Khurshid - Acquisition of data, Analysis and interpretation of data, Drafting the article, Final approval of the version to be published

\section{Guarantor}

The corresponding author is the guarantor of submission.

\section{Conflict of Interest}

Authors declare no conflict of interest.

\section{Copyright}

(C) Sheikh Javeed Ahmad et al. 2013; This article is distributed under the terms of Creative Commons attribution 3.0 License which permits unrestricted use, distribution and reproduction in any means provided the original authors and original publisher are properly credited. (Please see www.ijcasereportsandimages.com/ copyright-policy.php for more information.)

\section{REFERENCES}

1. Cassetta M, Gorevic PD. Crystal arthritis: gout and pseudogout in the geriatric patient. Geriatrics 2004;59(9):25-30. 
2. Kuo CF, Tsai WP, Liou LB. Rare copresent rheumatoid arthritis and gout:comparison with pure rheumatoid arthritis and a literature review. Clin Rheumatol 2008;27(2):231-5.

3. Baker DL, Stroup JS, Gilstrap CA. Tophaceous gout in a patient with rheumatoid arthritis. J Am Osteopath Assoc 2007;107(12):554-6.

4. Gomez MM, Carvajal JJD, Pastor MAAC. Gota tofácea: Indisciplina o desconocimiento? Medifam 2002;12(4):289-2.

5. Wooten M. Seronegative rheumatoid arthritis and gout. Clin Rheumatol 2005;24(1):91.

6. Reginato AJ. Gota e outras artropatias causadas por cristais. In: Kasper DL,Fauci AS, Longo DL, Braunwald E, Hauser SL, Jameson JL. Harrinson. Medicina Interna. v. 2, 16 ed., Rio de Janeiro: McGraw-Hill Interamericanado Brasil Ltda., 2006, pp. 2146-51.

7. Bachmeyer C, Charoud A, Mougeot-Martin M. Rheumatoid nodulesindicating seronegative rheumatoid arthritis in a patient with gout. Clin Rheumatol 2003;22(2):154-5.

8. Khosla P, Gogia A, Agarwal PK, Pahuja A, Jain S, Saxena KK. Concomitant gout and rheumatoid arthritis--a case report. Indian J Med Sci 2004;58(8):349-52.

9. Schapira D, Stahl S, Izhak OB, Balbir-Gurman A, Nahir AM. Chronictophaceous gouty arthritis mimicking rheumatoid arthritis. Semin Arthritis Rheum 1999;29(1):56-3.

10. Talbott JH, Altman RD, Yü TF. Gouty arthritis masquerading as rheumatoid arthritis or vice versa. Semin Arthritis Rheum 1978;8(2):77-114.

11. Brook RA, Forsythe A, Smeeding JE, Lawrence Edwards N. Chronic gout: epidemiology, disease progression, treatment and disease burden. Curr Med Res Opin 2010;26(12):2813-1.

12. Neogi T. Clinical practice. Gout. $\mathrm{N}$ Engl $\mathrm{J}$ Med 2011;364(5):443-52.

13. Lee SJ, Terkeltaub RA, Kavanaugh A. Recent developments in diet and gout. Curr Opin Rheumatol 2006;18(2):193-8.

14. Touart DM, Sau P. Cutaneous deposition diseases. Part II. J Am Acad Dermatol 1998;39(4 Pt 1):527-44.

15. Emmerson BT. The management of gout. N Engl J Med 1996;334(7):445-1.

16. Levinson DJ, Becker MA. Clinical gout and the pathogenesis of hyperuricemia. In: McCarty DJ, Koopman WJ, editors. Arthritis and allied conditions. 12th ed. Malvern, PA: Lea\&Febiger; 1993: 1773-806.

17. Dacko A, Hardick K, McCormack P, Szaniawski W, Davis I. Gouty tophi: a squamous cell carcinoma mimicker? Dermatol Surg 2002;28(7):636-8.

18. Grahame R, Scott JT. Clinical survey of 354 patients with gout. Ann Rheum Dis 1970;29(5):461-8.

19. Seegmiller JE. Skin manifestations of gout. In: Fitzpatrick TB, Eisen AZ, Wolff K, Freeberg IM, Austen KF, editors. Dermatology in general medicine. 4th ed. New York: McGraw-Hill;1993:1894-900.

20. Moschella SL. Miscelleneous rheumatic disease that can involve the skin. In: Sontheimer RD, Provost TT, editors. Cutaneous manifestations of rheumatic disease. Baltimore: Williams \& Wilkins;1995:243-57.

21. Lefkovits AM. Gouty involvement of the larynx. Report of a case and review of the literature. Arthritis Rheum 1965;8(5):1019-26.
22. Marion RB, Alperin JE, Maloney WH. Gouty tophus of the true vocal cord. Arch Otolaryngol 1972;96(2):1612.

23. Magid SK, Gray GE, Anand A. Spinal cord compression by tophi in a patient with chronic polyarthritis: case report and literature review. Arthritis Rheum 1981;24(11):1431-4.

24. Simkin PA, Campbell PM, Larson EB. Gout in Heberden's nodes. Arthritis Rheum 1983;26(1):94-7.

25. Scalapino JN, Edwards WD, Steckelberg JM, Wooten RS, Callahan JA, Ginsburg WW. Mitralstenosis associated with valvular tophi. Mayo Clin Proc 1984;59(7):509-12.

26. Gawoski JM, Balogh K, Landis WJ. Aortic valvular tophus: identification by X-ray diffraction of urate and calcium phosphates. J Clin Pathol 1985;38(8):873-6.

27. Ferry AP, Safir A, Melikian HE. Ocular abnormalities in patients with gout. Ann Ophthalmol 1985;17(10):6325 .

28. Martínez-Cordero E, Barreira-Mercado E, Katona G. Eye tophi deposition in gout. $\mathrm{J}$ Rheumatol 1986;13(2):471-3.

29. Fenton P, Young S, Prutis K. Gout of the spine.Two case reports and a review of the literature. J Bone Joint Surg Am 1995;77(5):767-1.

30. Holland NW, Jost D, Beutler A, Schumacher HR, Agudelo CA. Finger pad tophi in gout. J Rheumatol 1996;23(4):690-2.

31. Fam AG, Stein J, Rubenstein J. Gouty arthritis in nodal osteoarthritis. J Rheumatol 1996;23(4):684-9.

32. Fam AG, Assaad D. Intradermal urate tophi. J Rheumatol 1997;24(6):1126-31.

33. Vázquez-Mellado J, Cuan A, Magaña $\mathrm{M}$, et al. Intradermal tophiin gout: a case-control study. J Rheumatol 1999;26(1):136-40.

34. Perez-Ruiz F, Calabozo M, Pijoan JI, Herrero-Beites AM, Ruibal A. Effect of urate-lowering therapy on the velocity of size reduction of tophi in chronic gout. Arthritis Rheum 2002;47(4):356-60.

35. Khandpur S, Minz AK, Sharma VK. Chronic tophaceous gout with severe deforming arthritis. Indian J Dermatol Venereol Leprol 2010;76(1):69-71.

36. Kumar S, Gow P. A survey of indications, results and complications of surgery for tophaceous gout. $\mathrm{N} \mathrm{Z}$ Med J 2002;115(1158):U109.

37. Bertolo MB, Brenol CV, Schainberg CG, et al. Atualizacao do consensoBrasileiro no Diagnostico e Tratamento da Artrite Reumatoide. Rev Bras Reumatol 2007;47(3):151-9. 
Access PDF of article on other devices

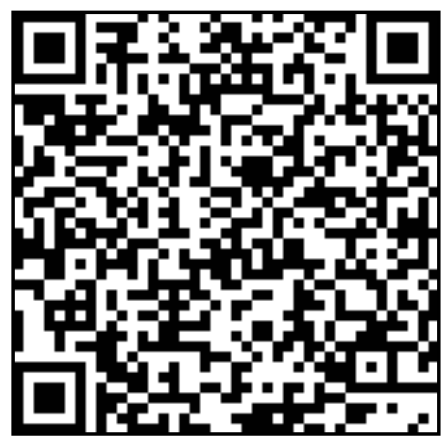

